\title{
The truth of personal names
}

\author{
Jõ̃o De Pina-Cabral University of Lisbon
}

Portuguese-speakers, when asked about their personal names, often respond with a notion of the 'truth of' their names. Basing itself on ethnographic data collected by the author in Macao (southern China), Bahia (Brazil), and Portugal, the article interprets this notion of truth as a form of ontological weighing that postulates the unitariness of the person by reference to a subjection to a bureaucratic order and to a cultural and linguistic universe associated to it.

This article attempts to grapple with a puzzle posed by the fact that Portuguesespeakers, when asked about their personal names, are prone to respond with answers that include a notion of 'truth'. Now, on the face of it, a name can be applied correctly or incorrectly, but it is not immediately obvious what can be more or less 'true' about a personal name that is correctly applied. Furthermore, as will be shown, what is at stake in this expression does not seem to be some sort of connotative logic - where the name may be taken to represent the person more or less adequately (see Pina-Cabral 2008a; Pina-Cabral \& Matos-Viegas 2007).

What can possibly be meant, therefore, by this sense of onomastic truth that is absolutely taken for granted by all of the Brazilians, Portuguese, and Macanese whom I have interviewed over the past decades concerning their personal names? ${ }^{1}$ What is this greater truth that they attribute to some of the names that they respond to? I start by presenting three cases (one from Macau, the other from Brazil and the final one from Portugal) and then go on to show how the phenomenon can be qualified in terms of three main factors that operate as conditions of truth: subjecthood, unitariness, and national/ethnic belonging. Finally, I construct a model of the notion's operation by taking recourse to the concept of 'ontological weight.'

\section{Mr Madeira's Chinese name}

Macao is a small peninsula in southern China which has played a role in the Portuguese state in one way or another ever since a commercial citadel was founded there in the late sixteenth century. Most of the sailors, soldiers, and merchants who 
occupied it then were already the product of a process of inter-ethnic mixing that had started in Malacca a few decades before but which has not stopped ever since (see Pina-Cabral 2002).

In 1987, Portugal signed an agreement with the People's Republic of China for the handing over of the city's administration in December 1999. For the Eurasian population, this agreement had enormous implications. It meant the end of what had been for over four centuries their major source of ethnic security, namely their informal control of the city's administration. Faced with this prospect, they felt they needed to know more about themselves, so they promoted studies of their city and of their own ethnic profile carried out by historians and anthropologists.

This is how I found myself in a café in Macao in the early 199os interviewing in Portuguese a middle-aged descendant of one of the older Eurasian families of the city. Macao is a multilingual city: Portuguese, English, and Cantonese have been mixing intensely in the city's streets ever since the British East India Company established its summer headquarters there in the mid-eighteenth century. Like most Eurasians born there from the 1920s to the late 1960s, my interlocutor was a fluent speaker of both Portuguese and Cantonese and expressed himself passably in English.

However, whilst his generation prides itself on its impeccable Portuguese (written and spoken), his children's generation on the whole feels more at ease in Cantonese and many have even started learning how to write Chinese. In turn, his parents' generation (now no longer living), who were brought up before the First World War, spoke a local form of the naval Creole that united the Portuguese seafaring empire in the sixteenth century; versions of which are still found in use today in such far-off places as Cape Verde, São Tomé, Casamanse, or Malacca (see Tomás 1992). As it happens, contrary to these places, Macao's patuá was abandoned during the period of intense colonial propaganda between the two world wars, and is no longer spoken, surviving merely as a language of tradition.

Ever since my first days in Macao I had become aware that the issue of personal naming was an area of inter-ethnic misunderstanding, leading to humorous comments and feelings of mutual discrediting between Portuguese, Macanese, and Chinese residents. In fact, most people in the city had adapted themselves to the multi-ethnic environment by adopting forms of what we might call polyonomastics.

Visiting cards, for example, a centrally important instrument in the everyday presentation of self in China, were being printed systemically by everyone with an alphabetic side and a side in Chinese characters. All might have been well if the name on both sides had indeed been the same, in the sense of being a simple translation, as when João is rendered as John in English or Jean in French. However, in Macao and Hong Kong there is no parallelism to the two names for the same person, since names in China and in Europe are constituted in strikingly different fashions (see Alleton 1993). Polyonomastics, therefore, are managed in an asymmetric fashion depending on whether the person self-identifies essentially with his or her Chinese name or with his or her European name. Having treated the subject at length elsewhere (see Pina-Cabral 1994), I will limit myself here to one of its aspects.

My interviewee's surname, Madeira, is usually translated into Cantonese as Ma, a common enough Chinese patronym. Now, for outsiders such as me, the Chinese name that we were given a few days after arriving in the Territory by some kind 
Chinese soul could hardly have been expected to play the role that our Portuguese name played, since it functioned as little more than a passing fancy. In Mr Madeira's case, however, this surname, Ma, was being used by his children, who spoke better Cantonese than Portuguese. Furthermore, it was also the way his father, his grandfather, and, presumably, his great-grandfather had been addressed by Cantonesespeakers. In short, this being an old name that had passed from father to son for many generations in parallel with the Portuguese name Madeira, the question arose in my mind as to how he felt about it. So, without thinking much of it, I asked him whether his Eurasian friends (all of them fluent speakers of Cantonese) also called him Ma.

As it turns out, the question displeased him. He explained emphatically that, if they had done so, they would have been offending him. His 'true' name (nome verdadeiro) was Madeira, and they should never use his Cantonese name, which had no other purpose than to facilitate communication with Cantonese-speakers. Evidently, much as it had been passed on in his family for a number of generations, the surname Ma did not characterize his personhood in the same fundamental way as did his Portuguese surname Madeira. Note, he did not say that the name Ma was 'false' in the sense of being incorrectly applied to him; he only insisted that the name Madeira was his 'true' name.

I recount this story because this is how I first became aware of the profound importance that this concept of 'truth' plays in Portuguese naming systems. Since then, I have had repeated occasion to remark on the notion's centrality. Let me then proceed with another case where it emerges in a slightly different light. This time the example is taken from my currently ongoing research into Brazilian ways of personal naming (see Pina-Cabral 2005; 2007; 2008a).

\section{The truth of Mademuazélia}

An acquaintance in São Paulo told me of a friend of hers, whom she had known for many years, who was universally called Zélia. In fact, this was even the name she used in her educational and professional documents. One day, this woman had shamefacedly confessed to my acquaintance that her reasonably common and pleasant enough name was not in fact her 'true' name. She was 'truly' called Mademuazélia. Her father had been charmed by the sound and the implications of the French word mademoiselle and had given her this 'invented' name in order to evoke these. She claimed that she 'hated' her name and did not allow people to call her it publicly as she felt it demeaned her.

Now, Portuguese and Brazilian legislations specifically forbid in no uncertain terms the change of given names. As it happens, in Zélia's case, owing to the potentially comical implications of her registered name, she would not have found it difficult to change it, as there are a number of judicial precedents in her favour. The fact is that, being already middle-aged, she had never even thought of doing it, though she did not have a ready explanation for why not.

This case is here taken as representative of an endless list of other cases I have encountered where people who have a personal name they claim to 'hate' or 'not to like' cannot bring themselves to contemplate the possibility of changing it. The way they explain themselves to me is that they feel they cannot really change their 'true' name since it was given to them by their parents. Stories are told of people who, having changed their name, suffered considerable emotional harm as a result. In one Brazilian 
case, I was even told of a group of siblings who refused ever to see their mother again after she not only divorced their father, which was common enough, but proceeded to change her given name. ${ }^{3}$

I have come to the conclusion that this kind of indissoluble association between person and name (and particularly given name, see Zonabend 1980) is not a specifically Brazilian thing but is an intrinsic part of a tradition of personal naming that is written into Portuguese-speakers in such a historically sedimented fashion that the bearers of these notions are not even aware of them as norms or as formulated values.

\section{Esmeralda unloved}

My final example is a cause célèbre in the Portuguese media that has repeatedly made the limelight over the past few years: the caso Esmeralda. This is the case of a young girl who was conceived in the course of a passing relationship. Approached by the mother, a Brazilian migrant in Portugal, the father refused to acknowledge paternity. Before returning home, the mother handed the newborn baby over to a childless couple under conditions that have not been precisely established. As a result of the declaration of unacknowledged paternity, however, the Public Prosecutor initiated a process of search for paternity, as the law demands. Following blood tests, the court eventually established that the mother's ex-boyfriend had indeed been the biological father of the child.

At this point, confronted with the legal obligation of accepting paternity, the man decided also to claim legal possession of the child, whom he had previously rejected. By then, however, the girl was 6 years old and the adoptive parents - as well as Portuguese public opinion - felt that the demand was motivated by reasons that were not to the child's best advantage. Nevertheless, the court of higher instance ruled against the adoptive parents and attributed the tutorship of the child to the biological father. This provoked a wave of popular protest in support of the young girl. By now she is about 8 years old and the process is far from over as it involves a series of other complications that are not relevant to our present concern.

The document in which the judges explain the basis of their decision is particularly interesting for us because of what it assumes concerning the nature of naming practices. I will quote from the court's verdict (acordão):

The facts established include three moments in which, if love for the minor Esmeralda had prevailed, we would assuredly not find ourselves where we are today ...

The court then goes on to itemize these instances, one of which is the following:

\footnotetext{
and we cannot fail to stress as a breach of personal identity the lack of legal justification for the alteration of her name, since the name that was given to her by her biological mother (progenitora) was 'Esmeralda'. Nevertheless, we know that she adopted the name Ana Filipa and that one of the manifestations of love for her necessarily involves not adding to her suffering in yet another way which has implications at the level of her 'self' and her relationship to others. ${ }^{4}$
}

Now, Esmeralda/Ana Filipa could not yet speak when she was placed in the care of her adoptive parents. What emerges from the statement, however, is that the judges considered the change of personal name a very serious damage to the child's selfhood. They 
treated it as definite evidence that suffering was inflicted upon her and as proof of lack of love justifying the interruption of the bond of adoptive filiation.

\section{My true name is ...}

Let us then address our broader topic. People may be called by names which they do not agree to, names which they do not recognize, or names which they do not appreciate. Still, this is hardly what happens normally. Most people readily acknowledge and respond to the names others use to call them. The fact is that, strictly speaking, at least in Lusophone contexts, no one responds to one name alone. ${ }^{5}$

In the simplest possible case, the person who is registered as Manuel da Cunha Santos will respond equally well whether he is called that or whether he is called Santos, Cunha Santos, or Manuel. But, under certain circumstances, he will also respond if he is called by means of a hypocoristic that refers to the official name, such as Nelinho or Mané. People are known to respond readily to nicknames, abbreviations, diminutives, pseudonyms, hypocoristics, and so on. Languages and cultures provide rules for the use, manipulation, and transformation of names that contemplate forms of polyonomastics (see Machado 1991 [1976]). The range of ways which cultures have of naming single people with different words is too large and complex to be subject to listing. ${ }^{6}$

What is to the point here is that, when I ask Portuguese-speakers about their names and the way they are used, the responses I receive depend invariably on a concept of onomastic truth - phrases like, 'Yes, they call me $X$, but my true name is $Y$ ' (o meu nome verdadeiro); 'Yes, they call me $X$, but my actual name is $Y$ ' (o meu nome mesmo); 'Yes, they call me $X$, but, in point of fact, my name is $Y$ ' (na realidade o meu nome é... or de facto, o meu nome é...).

What is the nature of this 'truth', 'reality', or 'facticity' that is so obvious to the speakers that it does not even require explanation? On the face of it, we would think that there can be no 'reality' or 'truth' to a name, since names are, by definition, linguistic conventions. What is being said then when 'truth', 'reality', and 'fact' are evoked by the speakers? If I respond to a name my whole life - as Zélia did in the above example - in what sense is this not my 'real' or my 'true' name? In what sense is Zélia less 'true' than Mademuazélia - the name that no one dares to call her? Why was Ana Filipa somehow ill treated by her adoptive parents for not having been called Esmeralda - a name she never even heard used as referring to herself? Why was Ma not Mr Madeira's true surname even although his ancestors and descendants used it for many generations?

It should be observed that the expression points to a notion of 'truth of' (verdade do nome) not 'truth in' (verdade no nome). In other words, what is at stake here is not the adequacy of the name to the naming process or the way the name reflects the named person more or less adequately (some sort of connotative logic). ${ }^{7}$ In our research in Bahia, we found out that around a quarter of the people interviewed claimed not to 'like' (gostar de) their given name or even to 'hate' it (odiar). In their everyday presentations of self, such people routinely include explanations of why their nome verdadeiro (true name) or nome mesmo (actual name) does not really represent adequately their personalities. Nevertheless, the notion that they should change their given name as a consequence of their dislike for it is rarely, if ever, entertained, as Zélia's case exemplifies.

The assumption that a person's name bears some 'truth', therefore, has nothing to do with whether it names the person adequately or not. When a man tells us that 
his pseudonym is not his 'true name', he is not telling us that it is being wrongly applied or that he does not agree with its use; he is not even saying that it is a 'lie'. He is only saying that there is a name that is truer than that one. When someone calls me Pedro, I do not reply that this is not my true name; rather, I reply 'that is not my name'. To the contrary, however, I have been heard to tell people who have called me John that, whilst I will respond to that name, my 'true name' is João.

So, if names like Zélia, Ana Filipa, or Ma are being adequately used but are not true, what is it then that is 'truer' in Mademuazélia, Esmeralda, or Madeira? Having probed my interviewees, I have come to the conclusion that 'truth' in names responds to three conditions: true names (a) are enshrined in the Civil Register, (b) relate to the physical person's unitariness, and (c) are in the language that best characterizes the person's dominant national or ethnic identity. Note, I did not say 'and/or', as the three conditions are all necessarily found in a name that is said to be 'true'; without one of them the others become questionable, losing some of their capacity to produce 'truth'.

Now, there is nothing necessarily universal about these conditions. The ethnographic record is filled with cases of societies and periods in which these conditions did not apply altogether or played a different role - compare, for example, Xavante modes of personal naming, as studied by Aracy Lopes da Silva (1986) in the wake of David Maybury-Lewis (1974). So, the first thing to establish is that this form of 'trueness' inheres in the Lusophone naming tradition and, more broadly, in the post-Iberian traditions. ${ }^{8}$ In fact, it plays a structuring role in the way personal names operate in such contexts.

\section{The Civil Register}

Let me start with the first-mentioned feature. When I ask people if their 'true' name is so-and-so and I happen to be wrong, they correct me promptly. ${ }^{9}$ The name that they correct me with is their 'full name' (nome completo) such as it is to be found in the Civil Register. What is at stake in this response does not seem to be onomastic adequacy, but rather the fact that some sort of greater onomastic validity is attributed to the full name as found in the Register. ${ }^{10}$

All of this would be easy to understand if the Civil Register had been a long-term feature of Portuguese and Brazilian societies. That, however, is not the case. The Civil Register was first instituted in the 1910 and its full implementation dates to the late 1920s. In Brazil, there are still rural people whose names are not to be found in the records - even though universal coverage has almost been achieved of late (see Schritzmeyer 2007). In Portugal, in any case, the enforcement of the Civil Register was not achieved without strife. It was one of the principal sources of popular dissatisfaction with the Republican regime in the period between the two world wars. In the short-lived counter-coup led by Paiva Couceiro in the north of the country (Monarquia do Norte, January/February 1919), the Civil Register was among the Republican reforms that the monarchists undertook to abolish. ${ }^{11}$ They meant to finish with the Civil Register not because they were against the principle of people's names being universally registered, but because they were against separating civil rule from ecclesiastical rule. In turn, the Republican policy of implementing a Civil Register did not aim to abolish the ecclesiastical records. Its aim was to separate political 
citizenship from religious adherence. ${ }^{12}$ The counter-revolutionaries (integralistas, as they were called) felt that this was taking away a central aspect of the cosmological integrity of the nation. ${ }^{13}$

Since then, the Civil Register has taken over the administrative role that was played for a long time by the ecclesiastical register, which has been kept universally in the Iberian Peninsula at parish level since the days of the Council of Trent (1545-63 - see Monteiro 2008). As it happens, parish records do not celebrate the same event as civil registers. Whilst the former are baptismal registers, the latter are birth registers. Admittedly, the two events conjoin metaphorically: baptism is canonically supposed to correspond to a kind of death and rebirth in Christ. The baptismal name, therefore, could be said to be 'truer' in some sort of mystical sense. But clearly that is not what is at stake. ${ }^{14}$ In spite of the fact that the Civil Register has now gained the upper hand, ${ }^{15}$ the name's trueness still did not vanish.

In sum, by treating as their 'truer' name the name that the state/church condones, my interviewees are giving evidence to the fact that their own constitution as persons is rooted in the order created by that state/church. Their name as is found in the Register is truer to the extent that it is the one that is ultimately valid in the eyes of the overarching authority - it is the name that determines their subjecthood.

\section{The name of the soul}

Another feature of truthfulness emerges clearly from Esmeralda/Ana Filipa's case. There, the judges take it as accepted that the name change has somehow harmed her because it caused 'a breach of personal identity'. This interpretation must be understood in the light of the different statuses that are attributed to the two parts of the name: the given name as opposed to the surnames. During the Middle Ages, people were known only by their given names. The modern concept of surname emerged slowly from earlier informal systems of naming based on patronymics, on place or house names or on nicknames. Only in the sixteenth century did the concept become dominant, and even then it was not universal. ${ }^{16}$

Contemporary Portuguese and Brazilian legal stipulations (post-1928) establish a clear difference between these two parts of the name. I have explored this issue more fully elsewhere (Pina-Cabral 2008b), so I will limit myself here to the observation that, whilst the law discourages strongly any form of name-changing, it explicitly forbids the change of given names as the latter is quintessentially the person's name. Examples such as the judges' ruling in the case of Ana Filipa/Esmeralda or Zélia's reluctance to abandon her given name corroborate what I heard in numerous interviews concerning how one's given name is somehow held to correspond more directly to one's inner self, whilst one's surname is taken to be ancillary.

In the days before the Civil Register, it was most common for women who were not heirs to entailed property to be named merely by their personal name in the ecclesiastical records (see Monteiro 2008). For example, my own great-great-grandmother is registered in the family tomb merely as 'Avelina de Arouca' - where the second part is not a personal name but the name of the county where she was born and from which she moved to the city where she was eventually buried.

It might be argued that the change that took place in the first part of the twentieth century from ecclesiastical records to civil records accompanied the adoption of a biologistic form of defining the person, since the occurrence registered in the records is 
no longer the baptism but the actual physical birth. In fact, the process has not stopped there. Since then it has been pushed back even further by the way in which parents have started giving names to foetuses immediately after knowing their sex as a result of the amniocentesis test (see Pina-Cabral 2005) or by the way in which the Roman Catholic Church has attributed the full status of personhood to foetuses.

The issue here is whether this type of biologism should be taken as a manifestation of a lay worldview that somehow naturalizes the person's inner self by no longer stressing the spiritual foundation but the physical foundation of the person. Were we to adopt such an explanation, however, we would be falling into the ideological trap that European polarizations of Nature vs Culture provide for us. Whilst it is true that the moment at which the person's inner self is defined is dependent today on biological formulations, this in no way implies that, as a result, some sort of abandonment of spirituality has occurred. We would be falling into the by now familiar modernist trap typified by the concept of 'secularization. ${ }^{17}$ To the contrary, what has occurred is that Christian opinion (and most notably that of the Roman Catholic Church) has accompanied this movement of pushing back of the essentialization of the person, making it dependent upon the moment of conception as formulated in presently dominant biological theories.

The notion that the person's essence is somehow integral and unitary, and that it is acquired at the moment of physical consolidation, has merely accompanied the evolution of conceptions concerning the physical formation of persons. Thus, much like the baptismal name in the old days, the given name today is still the name of the person's essence (no longer defined as 'soul' - alma - but as 'selfhood' - eu - as Esmeralda's judges put it).

Present-day 'lay' conceptions and legislations of naming, therefore, fall in line directly with the Iberian tradition's emphasis on the moment of physical consolidation as the moment of the person's formation. This is why historically the baby was not seen as being physically fully formed before baptism - the sacrament was taken to have direct physical implications. Baptism was formulated theologically as both a death and a rebirth, but it was seen as an essential tool of physical consolidation. ${ }^{18}$ In an interview in July 2005, a priest in a small coastal town in Baixo Sul (Bahia, Brazil) explained to me that he was regularly approached by local residents asking him to baptize children whose post-natal health was problematic. ${ }^{19}$ In the Alto Minho, in the first half of the twentieth century, pre-natal baptism was in fact used as a means of preventing miscarriage (see Pina-Cabral 1986: 135-7).

Furthermore, much like earlier formulations concerning the soul, present legal models also follow a pattern where the person's appearance is abrupt and integral whilst the person's vanishing is prolonged and tending towards eternity. This is why the notion of mortuary names, as found in so many cultures outside Europe, makes no sense in such a system. At the same time, whilst the soul's sacredness was explicitly formulated in earlier theological models, today's legal models seem to avoid mystical references. Nevertheless, this difference is in many ways merely apparent, as the person's integrity as manifested in his or her name continues to pertain to a value that is not merely pragmatic, but defines an essence - again the statement of Esmeralda's judges exemplifies the point.

Contemporary law establishes a clear point of departure for the person whilst allowing for a diffuse prolongation after death by assuring the eternal legal validity of the name of an entity the integrity of which far surpasses any sort of practical 
considerations. Whilst it is true that such a model of personhood applies to a sociocultural area far wider than post-Iberian cultures and societies, it cannot be taken in any way to be a universal feature of naming. ${ }^{20}$

\section{Ethnicity/nationality}

The final condition of onomastic truth that we will consider emerges clearly in $\mathrm{Mr}$ Madeira's example: names are somehow 'truer' in the language and form in which they were originally conceived and attributed. That is, whilst it may be possible to translate a name, this will diminish its essential truth. It is in this sense that Ma could never be $\mathrm{Mr}$ Madeira's 'true' name. The person's essence is characterized not only by a political referent and by a form of essentiality but also by some association to a determined world of meaning where language and culture conjoin to produce ethnic identity. The subjection to a state/church and the subjection to a language/culture of that state/church tend to merge in the trueness of a person's name - that is what Mr Madeira meant to explain. In this way, personal identity is centrally grafted to a bureaucratic order.

In some contexts this may be read as a nationalistic reference - as when Portuguese and Spaniards, or Brazilians and Argentineans, compare their differently formed names. In others, as is the case in Macao, the reference assumes ethnic implications. The study of Macanese Eurasians revealed that reference to the Portuguese language as manifested in personal naming was an integral part of local processes of ethnic differentiation (see Pina-Cabral 2002: 23).

This is why in socio-cultural contexts where ethnicity plays a role, a person who uses a 'translated' name will forever be 'discreditable' (as Goffman would put it - 1986: 41-3) on the implicit presupposition that he/she is hiding something essential about him- or herself. This was a common enough situation among older Portuguese migrants to the United States, whose efforts at integrating themselves into their new country in the post-war decades involved a process of shedding their original ethnic identity (e.g. João Rogério $=$ John Rodgers; Daniel Martins $=$ Dan Martin; José da Silva $=$ Joe Silver, etc. ) When I speak to such persons, my being Portuguese often elicits the original act of translation, but this always involves considerable awkwardness, suggesting a challenge to their moral integrity.

There are still other important implications that might be drawn from these observations. This is not the occasion, however, to expound at length on how name language issues are particularly relevant in colonial and post-colonial situations, where the language of the person's name may be either the colonial/national language or the local/traditional language and where the combinations and contextual adherences of the two may function as an integral part of the adoption of important political postures (see Firmino 2008 for the Mozambican case, and Feijó 2008 for the Timorese case).

\section{Ontological weight}

At this point it seems necessary to clarify some of the terms of our analysis. ${ }^{21}$ For too long, anthropologists have been working with a semiotic theory of representation that is arguably dependent on an 'essentially incoherent picture of the mind' (Davidson 2001: 52). More sophisticated theories of meaning are required which emphasize both the socially relational aspect and the fact that meaning is dependent on practical experience. In his otherwise misguided essay on 'The future of anthropology', Anthony Giddens suggests that anthropology ails from the uncritical adoption of a 
theory of meaning that is epistemologically unsound: '[T] hose who speak of a crisis of representation in anthropology, or who see anthropological work merely as a species of creative fiction, are the victims of a false theory of meaning. He traces the origin of this to the structural linguistics of Saussure and the way in which '[m] eaning is understood [there] in relation to a play of signifiers, not - as it should be - in the context of practical experience' (Giddens 1996: 124-5). A similar posture has been advocated by Johannes Fabian when he suggests that, going beyond semiotic uses of language in ethnography, we should explore 'the potential ... to move ethnography from a position that takes knowledge as representation to one that takes knowledge as praxis' (1995: 48).

This move, however, requires that we abandon this 'incoherent picture of the mind'. The problem is that it has become so deeply engrained in our anthropological traditions (analytical and methodological) and our intellectual tool-kit that we find it almost impossible to escape its grip, even when its noxious effects become apparent. In order to bring the question to the fore, it then becomes useful to hear how philosophers like Davidson formulate the problem:

\footnotetext{
In one crude, but familiar, version [of this picture of the mind] it goes like this: the mind is a theatre in which the conscious self watches a passing show (the shadows on the wall). The show consists of 'appearances', sense data, qualia, what is 'given' in experience. What appear on the stage are not the ordinary objects in the world that the outer eye registers and the heart loves, but their purported representations. Whatever we know about the world outside depends on what we can glean from the inner clues (2001: 34).
}

Contrary to this, he argues that

we have no use for the notion of purely private, subjective 'objects of the mind' ... Beliefs are true or false, but they represent nothing. It is good to be rid of representations, and with them the correspondence theory of truth, for it is thinking there are representations that engenders intimations of relativism (2001: 46).

To reject such a theory of meaning does not mean that we must reject the need to understand the processes of semantic integration that constitute the favoured paths in our universe of beliefs (Pina-Cabral 2004). It does mean, however, that 'identity' (personal or collective) can no longer be seen as a 'representation' but must be conceived as essentially plural and as a constant process of engagement with the panoply of objectifications that shore up sociality over time. Personal names (individual and collective) are perhaps one of the best instantiations of such a process.

Personhood, then, is a multi-layered, constantly emerging phenomenon based on an unspecified but large number of objectifications, among which names are doubtlessly one of the most central. ${ }^{22}$ As objectifications of the person's relational constitution, then, wherever they are used, personal names refer to and reinforce those aspects of personhood to which they are associated. When I respond to a pseudonym or a hypocoristic, I am, in this way, reinforcing those aspects of my personal identity that this name calls forth; when I respond willingly to a professional title appended to my patronym, I am also reinforcing and engaging those aspects of my personal identity that it evokes to my interlocutors. When, in a particular socio-cultural context, some mode of naming is consensually taken to have 'more existence' than others, as is the case in Lusophone naming practices, this means that the aspects of 
personhood and the relations that those names evoke are further legitimated. They are, as it were, placed above the level of fleetingness that characterizes everyday naming practices.

People can and constantly do 'work at' their mutual relationships by manipulating names - as pointed out above, there are loose rules for how to do this in each sociocultural context (e.g. I am often called in Portuguese by any one of a long list of distinct words depending on who speaks to me, and I can tell what the use implies about that person's relationship to me: João, Joãozinho, Juca, João'pá, João Paulo, Paulinho, Pina, Pina-Cabral, etc. - and here I only stay with those which are direct variations upon my 'true' name, for I have had to deal with many more in the course of my life). Each mode of naming only makes sense in terms of its contexts of attribution, acceptance, and use: that is, each mode of naming contains the reference to a series of aspects of personhood, which it validates or invalidates in the course of the naming process. These aspects of the person, therefore, are reinforced or repressed by the use of these modes of naming.

As we have seen, when my informants say that their 'true name' is $X$, they are not implying that someone else's name or some other name through which they may be known is 'false'. They are simply stating that this particular name is 'truer' or 'more real' than others. Thus, the matter is not one of denying the existence of some person, some relation, or some aspect of the person, but rather it is one of attributing, as it were, 'more existence' to some over others. Consequently, I will call this a matter of relative ontological weight.

Now, the nature of this ontological weight itself is not easy to determine - for, on the face of it, there is nothing more intersubjectively verifiable (let alone 'true', 'real', or 'factual', to use the emic expressions) in a hypocoristic or a pseudonym than in a name inscribed in the Civil Register. Furthermore, it would seem that what is at stake is not blocking off certain determined modes of personal constitution as represented by other modes of naming. Rather, it is a process of attributing greater importance to some aspects over others in personal constitution and, in this way, establishing an order of ontological precedence.

This order, it should be noted, presents itself not as an order of value but as an order of certainty. The names that are 'truer' (and the aspects of the person they qualify) are not said to be worth more; rather they are taken to have a fuller existence. There is no reduction of any other aspect of personhood - there is only the attribution of greater certainty to some aspects of personhood.

The process of ontological weighting that this kind of 'truth' establishes, then, is a matter of greater or lesser certainty. Strictly speaking, therefore, it is not existence that is at stake but confirmation: that is, a readiness to affirm existence. Some persons, relations, and aspects of personhood are less prone to being silenced, to being disconfirmed. But the possibility of wiping out (shutting off names that are effectively recognized, such as pseudonyms or hypocoristics) does not arise, since the fact that some naming process is presented as less 'true' does not seem to mean that it is 'false' - we have seen that from our examples. In sum, ontological weight is a process by means of which some aspects of personhood are less easily silenced than others; they are made to be more certain.

It is as if we were dealing again with the general issue of truth: what is at stake is never absolute truth but always establishing that there are things that are truer than other things. ${ }^{23}$ Ontological weight, then, would seem to be a question of recognizing a 
scale of certainty. We would be dealing, therefore, with confirmation. Now, confirmation is the relative adherence to some feature of reality over others (see Gil 1998). I no longer simply contemplate the existence of something; I have an investment in the existence of that thing. The existence of levels of greater or lesser 'truth' means that the process of personal naming implies an ordering of reality which attributes greater solidity to certain things and lesser solidity to others.

Therefore, the ontological weighting inscribed in Lusophone naming processes as reported above is the product of the adherence to a pre-established frame of ordering the world. It is a matter not of 'believing that' but rather of 'believing in' (see Ruel 2002 $[1982]) .{ }^{24}$ Relative truth here is a prop for a way of approaching the world that ties the person to a description of it that pre-exists the person but of which the person need not be in full cognizance.

\section{Names and modern bureaucracies}

Now, there are important implications for this argument. In her essay on 'The cloud god and the shadow self' (1995), Mary Douglas has argued that the style of personhood characteristic of modernity has important functional implications. Whilst one need not follow her in all of her opinions, there seems to be little doubt that, as she puts it,

in modern industrial democracy a composite person is unacceptable not for intellectual but for forensic and political reasons; in other words, it is an ideological problem ... Our legal system would not deliver our notions of justice if people could switch their identity back and forth and around. Our standard idea of the person corresponds to the accountability requirement of our judicial system (1995: 85-6).

As is so often the case in her writings, Mary Douglas's use in this passage of the 'imperial plural' (the unquestioned 'us' that functioned throughout the twentieth century as the constant comparative counter to the anthropological 'other') hides a set of presuppositions that similarly inhere in what Marilyn Strathern (1999) calls 'the Euro-American' subject. In this article, we have been dealing with naming practices that are characteristic of the Portuguese language roughly since the sixteenth century, so we have to distance ourselves from many of the more chronocentric implications of Douglas's analysis ${ }^{25}$ - note that she chooses features that are all on the side of 'good': the rule of law, democracy, industrial modernity, etc. What remains importantly from her argument, however, is that modern bureaucratic procedures presume a unitariness of the person that is consubstantial with Judaeo-Christian notions of the singularity of the soul and that are one of the foundations upon which modern ecclesiastical and political rule has been constructed in Western Europe and its colonies ever since roughly the sixteenth century. In the Lusophone tradition, 'truer' names rise above the flux of everyday relations; they are preserved by their formal status from the erosion to which their manipulation in the daily course of everyday relations might give rise. Thus, they give an appearance of permanence and inalterability that makes them indispensable instruments of bureaucratic control.

Note, however, that I am not stating that, in order for there to be a bureaucracy, you have to have persons whose objectifications as names is of this kind. I am aware, for example, that another major bureaucratic tradition in world history (namely the Confucian - see Alleton 1993) did not depend on a concept of the unified person as emerged in Western Europe. ${ }^{26}$ Mary Douglas declares that 'to be able to stand before a judge and 
make a sworn declaration about presence or absence from the scene of crime, a defendant has to be accountable as one person consistently in one body' (1995: 85). This declaration, however, begs a number of questions that are so obvious to a trained anthropologist that they hardly need specifying. Still, the association that she makes between a certain style of personhood and a certain style of bureaucratic control stands valid and, to my mind, must be taken into consideration when we approach one of the principal supports of personhood, the personal naming system.

To conclude, the 'truth of the name' - its ontological weight - indissolubly ties the person's constitution to the hegemonic order that establishes it: thus, seen as essences, ${ }^{27}$ persons are unitary and attached to a political and religious order and a socio-cultural tradition. However, whilst the ordering of the world depends on the existence of persons who think the world, the existence of persons depends on the pre-ordained order of the world. By responding to the name that is given to us at birth (or near it), we signal our docility before a pre-ordained world that establishes not only what can be true to us, but, most importantly, our own trueness.

\section{NOTES}

Research took place in Brazil between 2004 and 2008 subsidized by the Foundation for Science and Technology, Portugal (FEDER, POCI/ANT/61198/2004) and supported by the Institute of Social Sciences of the University of Lisbon. Research took place in Macao, between 1990 and 1999, subsidized by the Instituto Cultural de Macau (see Pina-Cabral 2002). The final revision of this article benefited from the outstanding conditions for research provided by the University of Chicago, where I was Tinker Professor during spring term, 2009.

${ }^{1}$ For a brief but competent description of Lusophone modes of personal naming, see http:// en.wikipedia.org/wiki/Portuguese_name.

${ }^{2}$ Concerning given names, Portuguese-speakers everywhere make an unquestioned distinction between 'names that exist' (e.g. esse nome existe) and names that, because they are 'invented' (inventado), are somehow odd; opposing, in this way, given names that are heralded by tradition to given names that are uncommon or had not been heard before. This opposition is another manifestation of the type of ontological weighing that this article addresses.

${ }^{3}$ It is worthwhile noting that, if she had chosen to change her surname instead of her given name, this would have caused no problem, surprise, or discomfort.

${ }^{4}$ Tribunal da Relação de Coimbra, see O Público 27 September 2007. I am grateful to Rui G. Feijó for having called this document to my attention. I attempted to translate as faithfully as possible, allowing for the incompetent formulation of the original.

${ }^{5}$ Incidentally, this is why it is methodologically misguided to study one mode of personal naming in isolation from others (given names, surnames, nicknames, hypocoristics, etc.). The various modes of naming are part of complex processes of naming in which they intermesh deeply. This is a problem, for example, that classically inconveniences scholars who are forced to rely on registers to study naming (see Dupâquier, Bideau \& Ducreux 1984).

${ }^{6}$ For a plurality of examples, see the collection of papers edited by vom Bruck and Bodenhorn (2006). The classic studies by Alleton (1993) on Chinese naming, by Maybury-Lewis (1974) and Lopes da Silva (1986) on Xavante naming, and by Zonabend $(1980 ; 1984)$ on French naming remain, however, inspirations.

${ }^{7}$ We might have tried to gloss 'trueness' as 'authenticity' or 'genuineness', as one of the reviewers of this article suggested, but this would not have covered the ground satisfactorily. Is the hypocoristic of my given name, to which I have responded my whole life through, any less 'authentic' or 'genuine' than my full formal name? The Portuguese people on whom I tried the question failed to see its point.

${ }^{8}$ Note that, whilst I claim ethnographic specificity to this feature, as I describe it, I am not denying that phenomena with considerable similarities do occur elsewhere. In her paper on Afro-American naming, for example, Susan Benson introduces a category 'names that are real' that might have benefited from a discussion along present lines, but that would have surely led elsewhere (2006: 195-7).

${ }^{9}$ As I have noted elsewhere (Pina-Cabral 2008a), Lusophone names are public to the extent that, if asked, people do not feel entitled to withhold their name except under very special circumstances. This is not universally the case in the ethnographic register. 
${ }^{10}$ Which is normally much longer than the name used in everyday situations. And, of course, there are rules for the legitimate transformation of one into the other. These are subconsciously known by everyone even though they seem not to deserve formulation. For example, whilst I have to write down my full name when I fill in the form for applying for a credit card, the name that appears on the card itself is a condensed form that I am free to choose. There are, however, a number of unspecified rules that constrain my choice which, for being unspecified, are none the less strongly compelling.

${ }^{11}$ Again I must thank Rui G. Feijó for calling my attention to this.

${ }^{12}$ And of course, since then, the Catholic baptismal register has been maintained; it has only lost administrative precedence. In my research on court cases involving disputed naming (Valença, Bahia, Brazil-2004/6), I found that the court routinely accepts baptismal records as corroborating proof of identity.

${ }^{13}$ Later, in 1928, the popular protest about the new norms of the Civil Register concerned something else, namely that they restricted the traditional freedom in the attribution of surnames that had characterized Portuguese onomastic practices during the modern era.

${ }^{14}$ The name in the baptismal register may not be precisely the same as in the Civil Register. People who reported instances of this to me always formulated it as a 'mistake'. They invariably attribute greater 'truth' to the name as found in the Civil Register.

${ }^{15}$ To the point that, in Brazil at least, the Catholic Church is advising its priests not to baptize children who have not previously been registered.

${ }^{16}$ For the Portuguese case, see Rowland (2008); more generally in Europe, see Bourin (1995).

${ }^{17}$ See Pina-Cabral (2001), as opposed to Casanova (1994), for example.

${ }^{18}$ Note the way the issue is formulated in the Catechism of the Council of Trent:

Finally, a name is given the person baptized. It should be taken from some person whose eminent sanctity has given him a place in the catalogue of the Saints. The similarity of name will stimulate each one to imitate the virtues and holiness of the Saint, and, moreover, to hope and pray that he who is the model for his imitation will also be his advocate and watch over the safety of his body and soul (my emphasis, see http://www.catholicapologetics.info/thechurch/catechism/ Holy7Sacraments-Baptism.shtml).

${ }^{19}$ In fact, I interpret the present dislike exhibited by the Brazilian Council of Bishops towards baptism at birth as a direct result of this change in the conception of the relation between the person's essence and his or her body.

${ }^{20}$ See, for example, the difficulties that its presupposition implies in the ethnography of Chinese populations, where the unitariness of the 'soul' cannot be presumed (see Pina Cabral 2002: 123-5).

${ }^{21}$ See, with slightly different implications, Pina-Cabral (2009). I am grateful to the anonymous referees of JRAI for the suggestion that I should develop further this part of the argument.

${ }^{22}$ This is not to be taken as an argument against the relative (because always incomplete) unitariness of the constituted self. It is, however, an argument against the objectification of the self and against an exclusive attention to conscious cognition as the basic mode of the person's engagement with sociality (see PinaCabral 2002: 120-5).

${ }^{23}$ For a similar perspective on the issue, see Fabian: 'Do misunderstanding and understanding relate to each other like error and truth? Perhaps a case could be made for misunderstanding as committing an error, but not for understanding as attaining truth' (1995: 41).

${ }^{24}$ See, on this matter, Sabbatucci's brilliant discussion of the history of 'fideism' (2000).

${ }^{25}$ And we are reminded of this by Marilyn Strathern herself in the unfortunate passages concerning Portuguese students in her Inaugural Lecture at Cambridge (1995).

${ }^{26}$ Even though, today, related sorts of problems seem to be arising in China (LaFraniere 2009). I thank Dain Borges for this reference.

27 ' [W] hilst being incapable of differentiating us from each other, the given name appears as an essential component of the person and, thus, of his or her identity' (Zonabend 1984: 26).

\section{REFERENCES}

Alleton,V. 1993. Les chinois et la passion des noms. Paris: Aubier.

Benson, S. 2006. Injurious names: naming, disavowal, and recuperation in contexts of slavery and emancipation. In The anthropology of names and naming (eds) G. vom Bruck \& B. Bodenhorn, 177-99. Cambridge: University Press. 
Bourin, M. 1995. L'écriture du nom propre et l'apparition d'une anthroponymie à plusiers éléments en Europe occidentale (Xie-XIIe siècles). In L'écriture du nom propre (ed.) A.-M. Christin, 193-213. Paris: L'Harmattan.

Casanova, J. 1994. Public religions in the modern world. Chicago: University Press.

Davidson, D. 2001. Subjective, intersubjective, objective. Oxford: Clarendon Press.

Douglas, M. 1995. The cloud god and the shadow self. Social Anthropology 3, 83-94.

DupÂquier, J., A. Bideau \& M.-E. Ducreux (eds) 1984. Le prénom: mode et histoire. Les entretiens de Malher 1980. Paris: Éditions EHESS.

FABIAN, J. 1995. Ethnographic misunderstanding and the perils of context. American Anthropologist 97, 41-50. Feıjó, R.G. 2008. Língua, nome e identidade numa situação de plurilinguismo concorrencial: o caso de Timor-Leste. Etnográfica 12, 143-72.

Firmino, G. 2008. Nomes dos vatonga de Inhambane: entre a 'tradição' e a 'modernidade'. Etnográfica 12, 129-42.

GidDEns, A. 1996. The future of anthropology. In In defense of sociology: essays, interpretations and rejoinders, 121-5. Cambridge: Polity.

GIL, F. 1998. Modos da evidência. Lisbon: Imprensa Nacional.

Goffman, E. 1986. Stigma: notes on the management of spoiled identity. New York: Simon \& Schuster.

LaFraniere, S. 2009. Name not on our list? Change it, China says. New York Times, 20 April (available on-line: http://www.nytimes.com/2009/04/21/world/asia/21china.html, accessed 8 February 2010).

Lopes Da Silva, A. 1986. Nomes e amigos: da prática Xavante a uma reflexão sobre os Jê. São Paulo: FFLCH-USP

Machado, A.M. 1991 [1976]. Recado do nome: leitura de Guimarães Rosa à luz do nome de seus personagens. São Paulo: Martins Fontes Ed.

Maybury-Lewis, D. 1974. Akwe-Shavante society. New York: Oxford University Press.

Monteiro, N.G. 2008. Os nomes de família em Portugal: uma breve perspective histórica. Etnográfica 12, 45-57.

Pina-Cabral, J. De 1986. Sons of Adam, daughters of Eve: the peasant worldview of the Alto Minho (NW Portugal). Oxford: Clarendon Press.

1994. Personal identity and ethnic ambiguity: naming practices among the Eurasians of Macau. Social Anthropology 2, 115-32.

2001. Three points on secularism and anthropology. Social Anthropology 9, 329-34.

2002. Between China and Europe: person, culture and emotion in Macao (LSE Monographs in Social Anthropology). Oxford: Berg; New York: Continuum.

2004. Os albinos não morrem: crença e etnicidade no Moçambique pós-colonial. In O processo da crença (eds) F. Gil, P. Livet \& J. de Pina-Cabral, 238-67. Lisbon: Gradiva.

2005. La soglia degli affetti: considerazioni sull'attribuzione del nome e la costruzione sociale della persona. Antropología 5, 151-72.

2007. Mães, pais e nomes no Baixo Sul (Bahia, Brasil). In Nomes: género, etnicidade e família (eds) J. de Pina-Cabral \& S. de Matos Viegas, 63-87. Coimbra: Almedina.

2008a. Outros nomes, histórias cruzadas: apresentando o debate. Etnográfica 12, 5-16.

2008b. Recorrências antroponímicas lusófonas. Etnográfica 12, 237-63.

2009. The door in the middle: six conditions for anthropology, In Culture wars: context, models, and anthropologists' accounts (eds) C. Toren, E. Plaice \& D. James, 152-69. New York: Berghahn.

— \& S. de Matos Viegas 2007. Nomes e ética: uma introdução ao debate. In Nomes: género, etnicidade e família (eds) J. de Pina-Cabral \& S. de Matos Viegas, 13-37. Coimbra: Almedina.

Rowland, R. 2008. Práticas de nomeação em Portugal durante a Época Moderna: ensaio de aproximação. Etnográfica 12, 17-43.

Ruel, M. 2002 [1982]. Christians as believers. In A reader in the anthropology of religion (ed.) M. Lambek, 99-113. Oxford: Blackwell.

SABBATUCCI, D. 2000. La prospettiva storico-religiosa. Rome: SEAM.

SCHRITZMEYeR, A.L.P. 2007. Nomes em julgamento: práticas judiciárias padronizando identidades sexuais. In Nomes: género, etnicidade e família (eds) J. de Pina-Cabral \& S. de Matos Viegas, 89-119. Coimbra: Almedina.

Strathern, M. 1995. The relation: issues in complexity and scale (Pamphlet 6). Cambridge: Prickly Pear.

1999. Property, substance, and effect: anthropological essays on persons and things. London: Athlone.

ToмÁs, M.I. 1992. Os Crioulos Portugueses do Oriente - uma bibliografia. Macau: Instituto Cultural de Macau. 


\section{Jõ̃o de PINA-CABRAL}

vom BRUCK, G. \& B. Bodenhorn (eds) 2006. The anthropology of names and naming. Cambridge: University Press.

Zonabend, F. 1980. Le nom de personne. L'Homme 20: 4, 7-23.

1984. Prénom et identité. In Le prénom: mode et histoire. Les entretiens de Malher 1980 (eds) J.

Dupâquier, A. Bideau \& M.-E. Ducreux, 23-7. Paris: Éditions EHESS.

\section{La vérité des noms de personnes}

\section{Résumé}

Interrogés sur leur nom personnel, les lusophones incluent souvent dans leur réponse une notion de «vérité » de ce nom. Sur la base de données ethnographiques recueillies par l'auteur à Macao (Sud de la Chine), à Bahia (Brésil) et au Portugal, le présent article interprète cette notion de vérité comme une forme d'évaluation ontologique qui présuppose l'unité de la personne par sa sujétion à un ordre bureaucratique et à l'univers culturel et linguistique associé à celui-ci.

João de Pina-Cabral (D.Phil. Oxon, Habil. Lisbon) is Research Co-ordinator at the Institute of Social Sciences of the University of Lisbon. He has been President of the Portuguese Association of Anthropology and of the European Association of Social Anthropologists. He is an Honorary Fellow of the Royal Anthropological Institute and a member of the Real Academia de Ciencias Morales y Politicas (Madrid) and of the Portuguese Academy of Sciences (Lisbon). He has published extensively on Northwestern Portugal, Macao (China), Mozambique, and Bahia (Brazil).

Institute of Social Sciences, University of Lisbon, Av. A. Bettencourt 9, PT160o-189 Lisbon, Portugal. pina.cabral@ ics.ul.pt 